\title{
Assessment of the Financial and Intellectual Value of a Research Library and its Application at the Idaho National Laboratory
}

Lynn E. Melander

Christine R. Garnier

August 2012

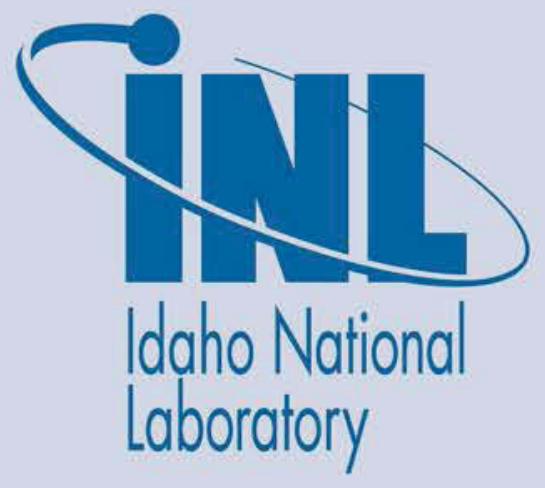

The INL is a U.S. Department of Energy National Laboratory operated by Battelle Energy Alliance 


\section{DISCLAIMER}

This information was prepared as an account of work sponsored by an agency of the U.S. Government. Neither the U.S. Government nor any agency thereof, nor any of their employees, makes any warranty, expressed or implied, or assumes any legal liability or responsibility for the accuracy, completeness, or usefulness, of any information, apparatus, product, or process disclosed, or represents that its use would not infringe privately owned rights. References herein to any specific commercial product, process, or service by trade name, trade mark, manufacturer, or otherwise, does not necessarily constitute or imply its endorsement, recommendation, or favoring by the U.S. Government or any agency thereof. The views and opinions of authors expressed herein do not necessarily state or reflect those of the U.S. Government or any agency thereof. 


\title{
Assessment of the Financial and Intellectual Value of a Research Library and its Application at the Idaho National Laboratory
}

\author{
Lynn E. Melander \\ Christine R. Garnier
}

August 2012

Idaho National Laboratory Idaho Falls, Idaho 83415

http://www.inl.gov

Prepared for the

U.S. Department of Energy

Office of Nuclear Energy

Under DOE Idaho Operations Office

Contract DE-AC07-05ID14517 



\begin{abstract}
Over the last several decades, libraries across the nation have undergone dramatic budget cuts, despite being an important resource for regional and national economic growth and innovation. Numerous studies have attempted to show that libraries increase the intellectual level of users and contribute to the economic growth of communities through surveys and customer service data. Within this study, we have attempted to develop a more analytical method for assessing library performance, using the Idaho National Laboratory Research Library as a sample subject. We have developed a mathematical model to measure the financial value of a library's material resources as well as its intellectual value to determine if the library is a positive contributor to the wider organization and community it serves.
\end{abstract}




\section{CONTENTS}

ABSTRACT. iii

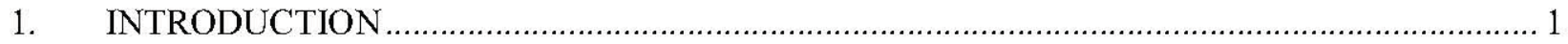

1.1 Previous Studies on Library Value and ROI..................................................... 1

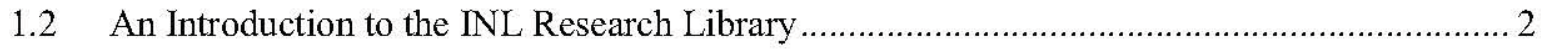

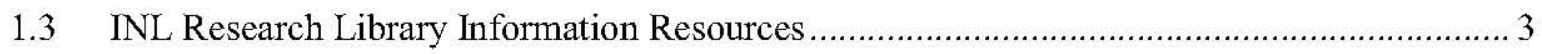

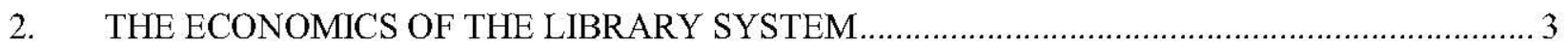

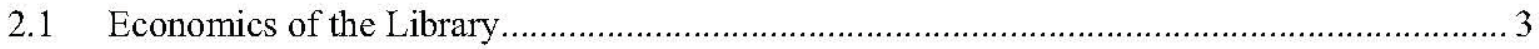

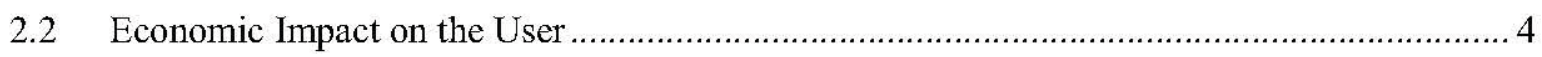

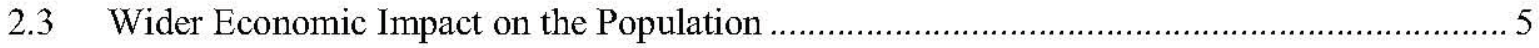

3. MATERIAL RESOURCES: FINANCIAL REPACEMENT VALUES ................................ 5

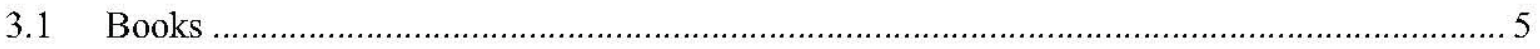

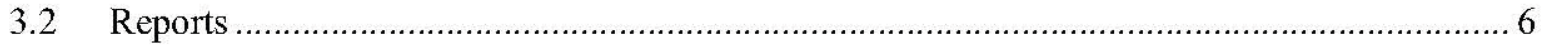

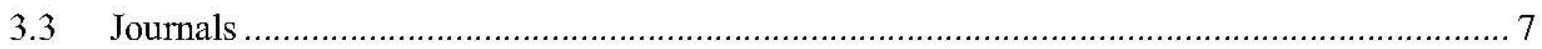

3.3.1 Appropriate Calculation of Sample Size ........................................................... 7

3.3.2 Weighting the data within Stratified Random Sampling ................................... 8

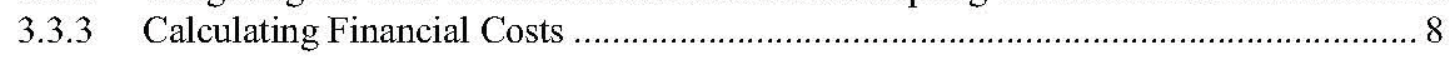

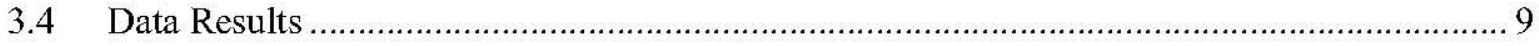

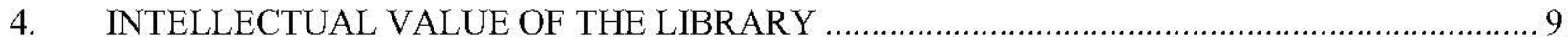

4.1 Behind the Intellectual Assessment Model ................................................................... 10

4.1.1 Input of Production: The Library's Resources and Services................................. 10

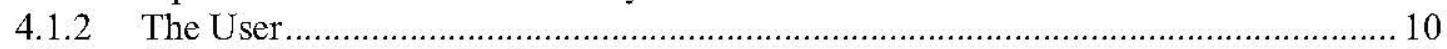

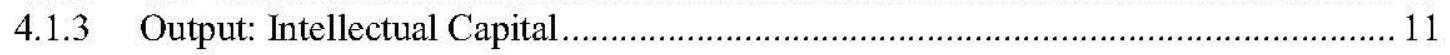

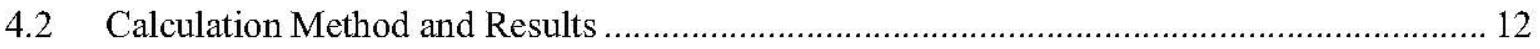

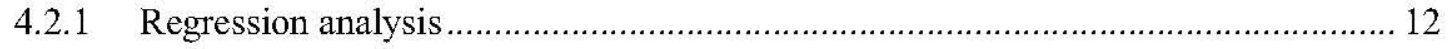

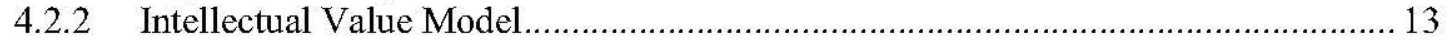

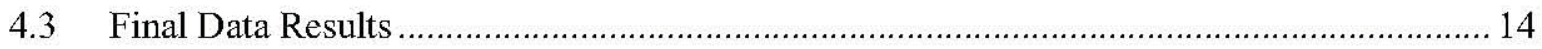

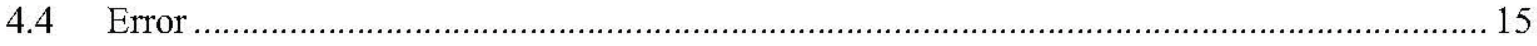

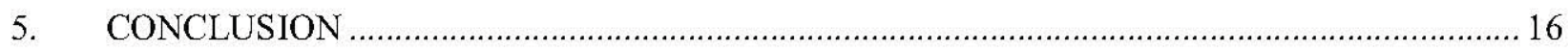

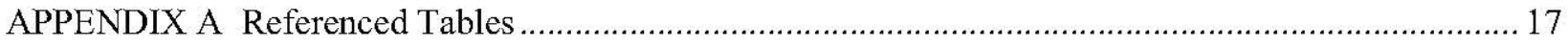

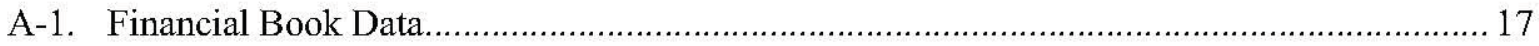

A-1.1 Book Subject Area Distribution by Year: Main, MFC, \& IRC Libraries............... 17 
A-1.2 Book Subject Area Average Replacement Cost and Availability per Item by Year: Main, MFC, \& IRC Libraries.

A-1.3 Book Subject Area Total Replacement Costs by Year: Main, MFC, \& IRC Libraries 19

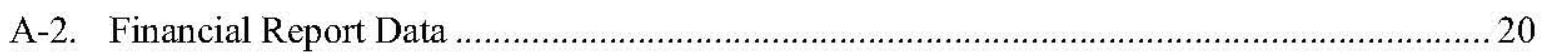

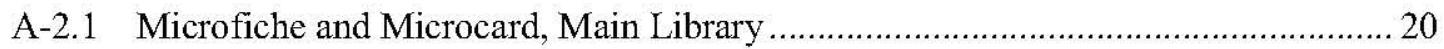

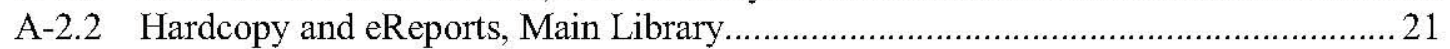

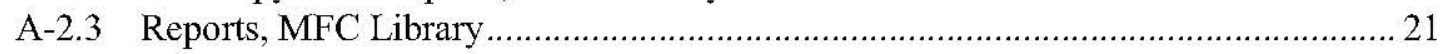

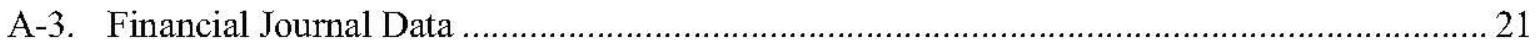

A-3.1 Weighted Sample Size by Journal Subject Area: Main, MFC, \& IRC

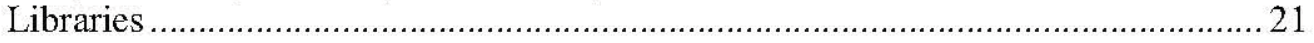

A-3.2 Depreciation Data and Averaged Factors ................................................ 22

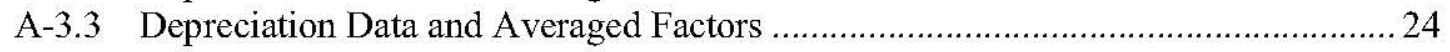

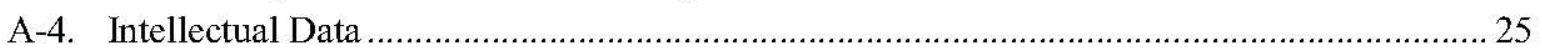

A-4.1 Input/Output Data Collected as measuring factors on INL .............................25

A-4.2 INL Input/Output Data changed to units of U.S.D. ...................................... 26

\section{FIGURES}

Figure 4-1. Total INL Employee Education. Bachelors and Graduate degrees represent the predominant research sectors of the Laboratory............................................................ 11

Figure 4-2. Input/Output comparison by year with third-degree polynomial function treads ................. 12

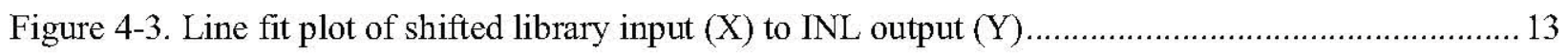

\section{TABLES}

Table 3-1. INL book replacement costs (for complete chart see Appendix A). ................................. 6

Table 3-2. Approximatedvalue of INL research library reports at the main.................................... 7

Table 3-3. Summary of depreciation Values (for full data see Appendix A) . ................................... 8

Table 3-4. Total estimated value of INL research library materials................................................. 


\section{Assessment of the Financial and Intellectual Value of a Research Library and its Application at the Idaho National Laboratory}

\section{INTRODUCTION}

The issue of assessing the actual intellectual and financial value of a library has become urgent among communities, educational institutions, corporations, and research organizations in the United States. Recent trends for commercial, private, public, and collegiate libraries show continuous decreases in financial support with negative accelerated trends during the recent economic downturn of $2007 .{ }^{1}$ In order to make proper decisions concerning investment in libraries, knowledge managers need to know the financial and intellectual impact their library has on the surrounding economy.

\subsection{Previous Studies on Library Value and ROI}

Previous studies on the economic impact of libraries have shown positive results for the surrounding community served. One study was conducted for the British Library, led by Nobel economists Kenneth Arrow and Robert Solow, to determine the nationwide economic impact of the library's services. After a thorough economic analysis, it was determined that the library's return on investment was 4.4 times annual government contributions to maintain the entire library: both collections and staff. Economic factors that were affected by the library included businesses and research institutions focused on innovation, thus increasing the competitiveness of the British economy. ${ }^{2}$

Similar economic studies have been conducted within the United States, on a state based level in South Carolina, ${ }^{3}$ Florida, ${ }^{4}$ and at the Carnegie Mellon Library ${ }^{5}$ in Pittsburg, PA. Many of these studies focus on the effectiveness and value of libraries; however, these studies do not use quantifiable data that validate the intellectual or economic impact of resources and services on a community or organization. This may be due to the difficulty in analytically measuring social, cultural, and economic impacts.

A common method used to appraise the value of a library is through customer surveys. For example, the study performed by the Carnegie Mellon Library used survey data to determine time and cost savings of library customers. The survey data was then used to determine the Carnegie Mellon Library's taxpayer dollar return on investment. Other studies have attempted to determine the value of libraries based on estimated customer cost savings for services ${ }^{6,7,8}$ or resource materials ${ }^{9}$ that might have been incurred by

\footnotetext{
1 "Library Expenditures as a Percent of University Expenditures for 17 ARL Libraries, 1966-2007". Association of Research Libraries. (22 May 2009), http://www.arl.org/bm doc/charts66-07.pdf.

${ }^{2}$ Pung, Caroline, Ann Clarke and Laurie Patten. "Measuring the Economic Impact of the British Library," New Review of Academic Librarianship 10, no. 1(2004): 87-90.

${ }^{3}$ Barron, Daniel, Robert Williams, Stephen Bajjaly, Jennifer Arns, and Steven Wilson. "The Economic Impact of Public Libraries on South Carolina: Executive Summary." University of South Carolina. (January 2005).

${ }^{4}$ Griffiths, Jose-Marie, Donald King, and Thomas Lynch. "Taxpayer Return on Investment in Florida Public Libraries: Summary Report." State Library and Archives of Florida. (September 2004).

${ }^{5}$ Carnegie Mellon University Center for Economic Development and Carnegie Library of Pittsburgh, Carnegie Library of Pittsburgh: Community Impact and Benefits, (April 2006).

${ }^{6}$ Sumsion, John, Margaret Hawkins, and Anna Morris. "Estimating the Economic Value of Library Benefits," Performance Measures and Metrics 4, no. 1 (2003): 13-27.

${ }^{7}$ Joseph R. Matthews, The Bottom Line: Determining and Communicating the Value of the Special Library, (Westport Connecticut: Greenwood Publishing Group, 2002).
} 
customers utilizing other information sources (i.e. bookstores, journal subscriptions). Additional studies focus on the possible cost benefits of using library services to find information that may result in project cost savings ${ }^{10,11}$ or $\operatorname{loss}^{12}$ associated with utilizing library services.

The drawback of these previous studies is that they have not developed a complete analytical method of determining the value of library service output and the effect of this output on organizations/communities. For example, the common use of customer surveys to assess library value is subjective in nature and may contain response biases or low participation rates that skew data.

Additionally, studies that attempt to tie library services to project outcomes may not be accurate measures of value due to the assumption that utilizing library services actually contributed to project outcome.

One key study focused on utilizing an analytical method to assess university publishing productivity based on library output measures. ${ }^{13}$ However, this study did not focus on measuring a single library's long term overall impact on the community or region served. Our research study attempts to go beyond these subjective and analytical methods by using input and output data collected from both a research library and its supported organization over a 15 year period. The data was compiled and analytically compared to associate value output from both organizations over time.

\subsection{An Introduction to the INL Research Library}

The Idaho National Laboratory (INL) supports and utilizes a research library. In operation since 1949, the INL is a Department of Energy research laboratory located in the southeastern Idaho desert. Today INL's mission has broadened into other areas, such as biotechnology, homeland security, materials research, and conservation/renewable energy. Vannevar Bush argues in Science: The Endless Frontier that advances in science promote innovation, national security and job creation; a nation weak in scientific research will also be weak economically. ${ }^{14}$ Scientific innovation, national security, job creation, and supporting economic growth are all goals of the INL.

The INL Research Library has served INL staff since 1952. During this time period the library has collected information materials in nuclear science, engineering, physics, chemistry, thermodynamics, fluid mechanics, mathematics, geosciences, materials science, energy, and computer science. These materials, which include both electronic and physical collections, are currently used by INL scientists and engineers to perform research and development activities. The INL's main purpose is to conduct research and development projects focused on a number of scientific and engineering issues that face the United States, including but not limited to nuclear test reactions, high-powered batteries for space travel, and high-quality material creation/generation.

The INL Research Library is attempting to create a world-class library that supports the expanding missions and initiatives of the INL by building upon the current collections and maintaining its excellent

\footnotetext{
${ }^{8}$ Griffiths, Jose-Marie and Donald W. King, Special Libraries: Increasing the Information Edge, (Special Libraries Association, 2003).

${ }^{9}$ King Research Inc., A Study of the Value of Information and the Effect on Value of Intermediary Organizations, Timeliness of Services and Products, and Comprehensiveness of the EDB, Publication No. DOE/NBM-1078, September 1984.

${ }^{10}$ Volpe National Transportation Services Center, Value of Information and Information Services, (U.S. Department of Transportation, October 1998)

${ }^{11}$ Frank H. Portugal, Valuating Information Intangibles: Measuring the Bottom Line Contribution of Librarians and Information Professionals, (Special Libraries Association, 2000).

${ }^{12}$ Susan Feldman, "The Cost of Not Finding Information," KMWorld 13, no 3 (March 2004).

${ }^{13}$ John M. Budd, "Faculty Publishing Productivity: An Institutional Analysis and Comparison with Library and Other Measures", College and Research Libraries 56, no. 6 (1999): 308-315.

${ }^{14}$ Bush, Vannevar. Science: The Endless Frontier. Washington: United States Government Printing Office, 1945 . p.16.
} 
service philosophy. In the future, the library's roles will be similar to those it presently fills: creating a learning and research environment, anticipating and responding to customer learning and research needs, contributing to positive publishing outcomes, and providing the information infrastructure necessary for cutting-edge research activities. The library links researchers with information, enabling the INL to achieve research excellence.

\subsection{INL Research Library Information Resources}

The INL Research Library provides materials and services to library customers. The library material collection contains three major types of hardcopy and electronic materials: books, journals, and reports. Library services are composed of four major types of individualized services: high level information research, in-house document delivery, interlibrary loan, and customer training.

The physical space of the INL Research Library is composed of a main library with three small satellite libraries. The purpose of the satellite libraries is to provide outreach services to researchers located throughout INL facilities separated by distances of up to 50 miles.

\section{THE ECONOMICS OF THE LIBRARY SYSTEM}

Knowledge based organizations, including libraries, are extremely important to today's information led society; yet, the value they contribute to economic growth is difficult to assess and may be underrated. For corporations and research institutions, the addition of a library has been shown to increase the economic growth of the organization. ${ }^{15}$ Yet to properly assess the intellectual and financial benefits added by a library, an elementary understanding of how the library is incorporated into the economy of the organization must be understood. The following is a theoretical analysis of how a research library serves a larger economy.

\subsection{Economics of the Library}

In classical economics, three different factors create economic value: land, labor and capital. Within an information based society, the power of knowledge becomes an asset central to the development of economic growth. The work of a research library aims to maximize access to knowledge for its constituents. ${ }^{16}$ This goal allows librarians to use the physical and human capital of the organization to promote intellectual capital, an asset that is considered more valuable than the three original variables, eventually developing into financial capital that correspond to the organization's mission. According to writer Peter Drucker, economic value within the current information age lies within productivity and innovation, which are both products of the application of knowledge to work. ${ }^{17}$ This places intellectual capital as one of the central assets of a company in the economy of the twenty-first century.

Intellectual capital was originally developed by economists at the end of the late 1980 's, pioneered by Thomas A. Stewart, author of "Intellectual Capital: the New Wealth of Organizations." In this book, he officially defines intellectual capital:

Intelligence becomes an asset when some useful order is created out of free-floating brain power that is, when it is given coherent form [...] when it is captured in a way that allows it to be described,

\footnotetext{
${ }^{15}$ Pung, Caroline, Ann Clarke, and Laurie Patten, "Measuring the Economic Impact of the British Library," New Review of Academic Librarianship 10, no. 1 (April 2004): 79-02.

${ }^{16}$ From the viewpoint of classical economics the library can be broken down into the three fundamental assets: land (physical space), capital (physical resources), and labor (librarians).

${ }^{17}$ Peter F. Drucker, Post-Capitalist Society (New York: HarperCollins, 1993).
} 
shared, and exploited; and when it can be deployed to do something that could not be done if it remained scattered around like so many coins in a gutter. Intellectual capital is packaged useful information. ${ }^{18}$

This simple philosophy of considering intelligence as an economic asset is the foundation for the information age. The purpose of a research library is to filter through intellectual material ${ }^{19}$ and prepare intellectual capital for researchers to develop innovative ideas.

\subsection{Economic Impact on the User}

The information services offered by a library, filter information within the library's internal and external sources inclusively, then impacting the external user. This information is condensed and presented to the recipient for his/her own personal knowledge generation.

The library acts as an indirect investment in human capital, because it presents the user with information in a concise form allowing for effective education for various goals. This is considered a general investment in human capital that cannot be separated from previous knowledge, skills or health, unlike measures of financial or physical capital.

An increase in an individual's human capital can expand the creative possibilities of the individual. In the case of the scientist, the access and exposure to background information for a project is highly beneficial. According to Jo Bryson, "Libraries can assist in the innovation process by linking researchers with information about potential users, public and private sector grants and investment schemes that turn a good idea into a commercial product." 20

Researchers that utilize their access to paid information tools, like research libraries, are $87 \%{ }^{21}$ more likely to succeed in their research activities and $90 \%$ of researchers who work with librarians believe that the librarian made significant contributions to their research efforts. ${ }^{22}$

A research library acts as an essential connection between the research institution and other research that has been and is being conducted throughout the rest of the world. According to library research experts Paul B. Kantor and Tefko Saracevic, "In the sciences, good library and information services are considered indispensable for research ... special libraries provide information that is considered essential for research, management, conduct of business, competitive position, and the like. [Therefore, libraries] have value for the organization as a whole." ${ }^{23}$ Where there is an active economy, the need for access to new, energizing information is present.

For a national research institution with a highly educated population, like $\mathrm{INL}^{24}$, an increase in intellectual and human capital for researchers and scientists will lead to a significant increase in innovation because these sectors explore different areas of science and there is no direct 'in-house' competition. This information and innovation becomes a basis for future research innovation. Creativity,

${ }^{18}$ Thomas A. Stewart, Intellectual Capital: The New Wealth of Organizations (New York: Doubleday, 1997): 67.

${ }^{19}$ Anything that provides information whether or not it is pertinent to the organization.

${ }^{20}$ Jo Bryson, "Measuring the Performance of Libraries in the Knowledge Economy and Society," Australian Academic and Research Libraries 32, no. 4 (December 2001): 338-339.

${ }^{21}$ Martin Akel \& Associate, A Study of Correlation: The Effect of R\&D Information Tools on Research Success (Chester, New Jersey: commissioned by Reed Elsevier Publishing, 2005).

${ }^{22} \mathrm{Ibid}$.

${ }^{23}$ Kantor, Paul B. and Tefko Saracevic. "Studying the Value of Library and Information Services. Part 1. Establishing a Theoretical Framework," Journal of the American Society for Information Science 48, no. 6 (1997):538.

${ }^{24}$ Staff education levels have been fairly consistent at the INL over the past 15 years with $22 \%$ Graduate, $26 \%$ Bachelors, $14 \%$ Associates, $12 \%$ Technical and $26 \%$ High School or less. 
the starting element of innovation, does not develop within a vacuum; a library's services act as an efficient link to current information.

\subsection{Wider Economic Impact on the Population}

While the more obvious impact of a research library's services is directly upon the user, the services can have a wide reaching impact on the total population (i.e., university, corporation, and nation). With an increase of a population's human and intellectual capital, information is openly shared between people and organizations. From this flow of information, more education and human capital is fostered, igniting more innovation that applies to various overlapping sectors within an organization.

This idea is reflected within the endogenous growth theory developed in the 1980's to promote economic growth within developing economies. The theory consists of a two sector model, dividing the population into an educated population (research community) and the rest of the population (manufacturing community). The general theory behind this two sector model is that a larger educated population will result in faster sustainable growth. By infusing an already educated population, such as the INL, with information that meets or rivals the user's initial intellectual capacity, the educated population grows - resulting in sustainable intellectual and economic growth for the organization.

Intellectual and economic impact is not only important for a federal facility, such as the INL, but also for the surrounding community. An increase in economic growth, fostered by employment opportunities at INL or through intellectually fostered spin-off companies, infuses income into the local economy. ${ }^{25}$ The INL Research Library's main goal is to support research that not only generates intellectual property for the INL, but disperses this intellectual property throughout the region and nation to improve the quality of life of US citizens.

\section{MATERIAL RESOURCES: FINANCIAL REPLACEMENT VALUES}

To properly assess the material replacement value of the INL Research Library, sampling methods were used to approximate the value of each major material resource category within the library: books, reports and journals. Dividing materials into categories and separately calculating replacement value is important because each category has differences in distribution and pricing methods. It is more effective to divide the different resource types into categories for the calculation of their financial value.

\subsection{Books}

The calculation of the financial value of the complete book section of the INL Research Library was completed through a non-statistical survey method. Books were broken down into subject area and then into year increments. Data was obtained using the Research Library's catalog database with the main library book collection numbering approximately 46,000 and satellite library book collections numbering approximately 11,000 items (see Appendix A-1.1). Book subject area divisions were based on Library of Congress call numbers. ${ }^{26}$

\footnotetext{
${ }^{25}$ Black, Geoffrey, Don Holley and John Church. Impacts 2001: An Analysis of the INEEL's Impact on Idaho 's Economy. (Idaho National Laboratory, 2001): 7.

${ }^{26}$ Library of Congress number system: Technology, Engineering $(T)$, Science $(Q)$, Business and Economics $(H)$, Health $(R)$, Geography and Environment (G), Law (K), Information Science (Z), Agriculture (S), Reference works (A), Military and Naval (U, V), Government (J), Education (L), and Other (B, N, C, E, F, D, M, P).
} 
Approximate book costs were calculated by subject area and year. Financial data for this survey was obtained from booksellers to approximate used book cost and availability (see Appendix A-1.2). The book data for 2000-2008 is based on average INL Research Library new book purchases over this time period.

During the survey it was determined that approximately $33 \%$ of the books within the library's collection, despite being included in the survey population, are considered irreplaceable. These books are no longer available in print or for purchase from booksellers.

Using this sampling method, the estimated total replacement costs were calculated. The cost was calculated by multiplying the number of books by the estimated average item replacement cost for each subject area (see Appendix A-1.3).

Table 3-1. INL book replacement costs (for complete chart see Appendix A).

\begin{tabular}{|l|r|}
\hline \multicolumn{1}{|c|}{ Subject Area } & \multicolumn{1}{c|}{ Total } \\
\hline Technology, Engineering & $4,373,132$ \\
Science & $2,534,648$ \\
Business, Economics & 156,387 \\
Health, Medicine & 302,727 \\
Geography, Environment & 151,319 \\
Law & 32,864 \\
Information Science & 30,215 \\
Agriculture & 60,586 \\
Reference Works & 60,586 \\
Military, Naval & 16,516 \\
Government & 5518 \\
Education & 5518 \\
Other & 32,854 \\
\hline Total & $\$ 7,762,870$ \\
\hline
\end{tabular}

The result of this non-statistical survey placed the value of the INL Research Library's book collection at approximately $\$ 7,762,870 .{ }^{27}$

\subsection{Reports}

The financial value of the report section of the INL Research Library was determined through the average cost calculated from INL Research Library NTIS ${ }^{28}$ account purchase statements in 2008. NTIS account statements list the cost of reports purchased by the INL Research Library and represent a range of subjects.

The microfiche portion of the report section were separated by topic area by calculating the approximate percentage of reports historically purchased through the Selected Research in Microfiche service by the total microfiche and microcard holdings (see Appendix A-2.1.) The number of hardcopy

\footnotetext{
${ }^{27}$ This number is conservative and does not reflect high priced or irreplaceable materials.

${ }^{28}$ National Technical Information Service is operated by the U.S. Department of Commerce.
} 
and electronic reports was determined by approximating the number of reports on library shelves and through the library catalog database data (see Appendix A-2.2 and A-2.3.)

Based in this information the average INL cost in 2008 for one report of various media (i.e., electronic, microfiche, print-on-demand) is approximately $\$ 31.12$. It should be noted that this average cost excludes special high cost reports such as EPRI and potential duplicate reports.

Table 3-2. Approximated value of INL research library reports at the main.

\begin{tabular}{|l|r|}
\hline Total Number of Reports & $1,419,100$ \\
Average Cost Per Report & $\$ 31.12$ \\
\hline Total Replacement Value & $\$ 44,162,392$ \\
\hline
\end{tabular}

The financial replacement value of the reports section in the INL Research Library, in 2008, is $\$ 44,162,392$. This represents the most important section of the library, and a key information resource for researchers and scientists at INL.

\subsection{Journals}

To calculate the overall value of the library materials, each resource type complied of its own population entirely to estimate financial values. For the appropriate application of statistics, we concentrated on the journal section (the largest section by volume in the library) and divided the section into scientific topic subcategories or various strata.

\subsubsection{Appropriate Calculation of Sample Size}

After the total number of items was calculated for each category, the sample size for estimating the financial value of the journal section was determined. Because no previous data or research has been done on the Library's assets, primary statistical measures are unknown (standard deviation, level of variation, etc.). Thus the application of Yamone's simplified sample size formula ${ }^{29}$ is sufficient because the level of variation of the financial data is ultimately unknown.

$$
\begin{aligned}
& \mathrm{n}_{0}-\underline{\mathrm{N}} . \\
& 1+\mathrm{N}(\mathrm{e})^{2} \\
& \mathrm{~N}=\text { finite population size of the resource type } \\
& \mathrm{e}=\text { estimated error expected (within this study, } 5 \% \text { error was expected) } \\
& \mathrm{n}_{0-} \text { necessary sample size (assuming sampling with replacement) }
\end{aligned}
$$

However, because the sampling will be done without replacement, it needs to be multiplied by a correction factor. The formula for the final sample size will be:

$$
\mathrm{n}_{\mathrm{f}-\mathrm{n}_{\mathrm{o}}} * \sqrt{ }\left(\left(\mathrm{N}-\mathrm{n}_{\mathrm{o}}\right) \div(\mathrm{N}-1)\right)
$$

Thus the final sample answer $\mathrm{n}_{\mathrm{f}}$ will be the size of the total sample for the journal section.

\footnotetext{
${ }^{29}$ Taro Yamane, Statistics, An Introductory Analysis, 2nd Ed. (New York: Harper and Row, 1967): 886.
} 


\subsubsection{Weighting the Data within Stratified Random Sampling}

By calculating the percent each subcategory represents out of the entire resource population, ${ }^{30}$ the application of stratified sampling can be weighted to fully reflect the contents of the collection.

$$
\begin{aligned}
& \mathrm{n}_{\mathrm{s}}=\mathrm{n}_{\mathrm{f}} * \mathrm{p}_{\mathrm{c}} \\
& \mathrm{n}_{\mathrm{s}-} \text { number of data points that are to be pulled from that particular subcategory } \\
& \mathrm{n}_{\mathrm{f}}=\text { sample size without replacement } \\
& \mathrm{p}_{\mathrm{c}}=\text { percent of the resource type the subcategory represents }
\end{aligned}
$$

By multiplying the proportion of the subcategory by the total necessary sample size, each stratum is assigned a number that relates to the amount of data points that should be pulled from that stratum. The amount of data to be pulled from each subcategory represents the prevalence of that subcategory in the entire collection (see Appendix A-3.1).

\subsubsection{Calculating Financial Costs}

Data concerning the replacement value of the datum point must be drawn from the population at random to represent the true population as close as possible. To properly reflect the current value of the journal collection, a general depreciation method was applied to the calculation of the final value. Each data point was broken down into years subscribed, and the number of years was broken down into year segments. Each section was multiplied by an average depreciation factor for each decade (see Appendix A-3.2).

Since depreciation is linear for print values, the following linear expression represents the rate of depreciation used within this study: $y=0.01246 x-0.6121$. The $x$-intercept represents the year 1949 , the year the INL was founded.

Table 3-3. Summary of depreciation values (for full data see Appendix A).

\begin{tabular}{|r|c|}
\hline Decade & $\begin{array}{c}\text { Depreciation Factor } \\
\text { (DF) }\end{array}$ \\
\hline past-1960s & 0.240 \\
$1970 \mathrm{~s}$ & 0.304 \\
$1980 \mathrm{~s}$ & 0.407 \\
$1990 \mathrm{~s}$ & 0.538 \\
$2000 \mathrm{~s}$ & 0.746 \\
\hline
\end{tabular}

For each data point, the following formula was used to calculate the number of depreciated years that the point would represent in relation to the 2009 price of that journal subscription.

Depreciated years for data point $\mathrm{x}=\left(\right.$ \#years past-1960s $\left.^{*} \mathrm{DF}_{\text {past-1960s }}\right)+\left(\right.$ \#years $\left.{ }_{1970 \mathrm{~s}} * \mathrm{DF}_{1970 \mathrm{~s}}\right)+$ $\left(\#\right.$ years $19_{80 \mathrm{~s}} *$ DF $\left.19_{80 \mathrm{~s}}\right)+\left(\right.$ \#years $19_{90 \mathrm{~s}} *$ DF 1990s $)+(\#$ years 2000s $*$ DF 2000s

Multiplying the total depreciated rate by the current 2009 price for each sample journal, results in the total value for that specific data point within the Research Library's journal collection. ${ }^{31}$ By repeating this

\footnotetext{
${ }^{30}$ This can be accomplished by taking the total number of items in the subcategory, say the number of volumes within the chemistry category, under journals, and dividing it by the total number of journals within the collection.
} 
process for the entire sample, and adding the data points together, the result will be the total value of the sample size. By dividing the total value of the sample size, by the total number of journals included in the sample size, $\mathrm{n}_{\mathrm{f}}$, the result is the average or mean value for a journal set in the Library's collection. The total number of journals held within the INL Research Library is multiplied by this average journal value, resulting in the estimated total value of the complete journal collection (see Appendix A-3.3).

The final replacement value estimate for the journal collection in both print and electronic format is $\$ 41,694,847^{32}$ with the print section alone estimated at $\$ 34,472,610 .^{33}$

\subsection{Data Results}

Through the calculations of the individual sections of the book, report and journal collections of the INL Research Library, an estimated total replacement value can be made. The total financial replacement value of the INL Research Library material is approximately $\$ 93,620,109$. This value is conservative and does not reflect high cost or irreplaceable resources.

Table 3-4. Total estimated value of INL research library materials.

\begin{tabular}{|lc|}
\hline & Estimated Value \\
\hline Book Collection & $\$ 7,762,870$ \\
Report Collection & $\$ 44,162,392$ \\
Journal Collection & $\$ 41,694,847$ \\
\hline Total value: & $\$ 93,620,109$ \\
\hline
\end{tabular}

\section{INTELLECTUAL VALUE OF THE LIBRARY}

Since its establishment at the beginning of the technology age, intellectual capital has been referred to as the growing tool that companies can create. According to Nick Bontis, information will double approximately every 11 hours by the year $2010 .{ }^{34}$ Yet many economists have deemed that calculating the actual value of intellectual capital is much more complicated then identifying its existence. This is because intellectual capital is impacted by numerous factors, both qualitative and quantitative. Yet as time has progressed, economists have realized that this intangible asset is also intertwined with human capital. To construct any model on intellectual value, you must have at least two variables: the source where knowledge is entering the organization and education of the user.

Most intellectual capital models used today have been developed within the past fifteen years. According to Stewart, NCI Research was one of the first organizations to develop a method of calculating

${ }^{31}$ It should be noted that the INL Research Library's journal collection also exists of online subscriptions. Those years are included within the study, but instead of multiplied by the depreciation factor, they were multiplied by $10 \%$, the value that most publishing companies value the addition of an online subscription of the normal print subscription. This method is used by major publishers like Emerald, Elsevier, and Wiley InterScience Publications. This resulting number was added into the years of each data point for one part of the study, which resulted in the total value of the journal section (print and online), only. It did not factor into the print only calculations of this study.

${ }^{32}$ A small percentage of the Library's online journal access can only be accessed by year to year subscription. This percentage is so small that it would not severely affect the final value of the complete journal collection. With a $5 \%$ statistical error the value is between $\$ 39,610,105$ and $\$ 43,779,589$.

${ }^{33}$ With a $5 \%$ statistical error the value is between $\$ 32,748,979$ and $\$ 36,196,241$.

${ }^{34}$ Nick Bontis, "Assessing knowledge assets: a review of the models used to measure intellectual capital," International Journal of Management Reviews 3, no. 1 (March 2001): 41-60. 
intellectual capital. ${ }^{35}$ Some models focus on efficiency and components of intellectual capital, such as determining human capital and structural capital values like Skandia's Navigator, ${ }^{36}$ applying a dollar value after qualifications are met and questions are answered, ${ }^{37}$ using citation-weighted patents, ${ }^{38}$ or by calculating the company's book value and subtracting accounting factors like in the Sveiby method and the Economic Value Added method. ${ }^{39,40}$

These methods are complicated and structured towards evaluating a corporation in its entirety. Most libraries do not have the variables required to develop these types of models, or at least access to the type of information needed to assess their intellectual capital using these methods. Therefore we have developed a simple method to assess positive or negative intellectual growth impacts of a library with limited independent and dependent variables.

\subsection{Behind the Intellectual Assessment Model}

This model strives to focus on the most crucial factors of library and organizational output to determine a correlation of both outputs. A mathematical assessment was made to estimate the impact the library has on the organization's intellectual output. The model is geared toward a research library; however the method could be tailored for use by all libraries.

\subsubsection{Input of Production: The Library's Resources and Services}

One of the key measures used in this model is not the library budget itself, but a set of carefully divided and calculated measures of library output. In a study by Lewis Guodo Liu on cost function and scale economies in Academic Research Libraries, output measures of a library were determined to be group presentations, reference transactions, interlibrary loans borrowed and lent, and total number of circulated items. ${ }^{41}$ For the purpose of this study, INL Research Library output data analyzed included: number of information research training seats filled, use of the INL Research Library's web based resources, interlibrary loans borrowed ${ }^{42}$, information service requests ${ }^{43}$, and publications budget. This represents the INL Research Library's key service activities.

\subsubsection{The User}

The users of information are a key factor in calculating the intellectual value of a library, because they act as the connection between the library and innovative ideas. For most libraries, the user consists of a diverse population. At the INL, the user demographic is more condensed. INL Research Library

\footnotetext{
${ }^{35}$ Thomas A. Stewart, Intellectual Capital: The New Wealth of Organizations (New York: Doubleday, 1997): 227.

${ }^{36}$ Edvinsson, Leif and M.S. Malone, (1997). Intellectual Capital: Realizing Your Company's True Value by Finding its Hidden Brainpower. New York: HarperBusiness.

${ }^{37}$ Anne Brooking, Intellectual Capital: Core Assets for the Third Millennium Enterprise (London: Thomson Business Press, 1996).

${ }^{38}$ L.E. Lynn, The Management of Intellectual Capital: The Issues and the Practice, Management Accounting Issues Paper 16, Management Accounting Practices Handbook (Hamilton, Ontario: Society of Management Accountants of Canada, 1998).

${ }^{39}$ K.E. Sveiby, The New Organizational Wealth: Managing and Measuring Knowledge-based Assets (San Francisco: BarrettKohler, 1997).

${ }^{40}$ N. Brontis, "Intellectual Capital: An Exploratory Study That Develops Measures and Models," Management Decisions 36, no. 2 (1998): 63-76.

${ }^{41}$ Lewis Guodo Liu, "The Cost Function and Scale Economies in Academic Research Libraries," College and Research Libraries 63, no. 5 (2003): 406-420.

${ }^{42}$ The source of this information was collected on 8 July, 2009 from Tamera Waldron, the Interlibrary Loan Coordinator for the Idaho National Laboratory.

${ }^{43}$ Service transactions include high-level literature and data research, materials circulation, and various other customer transactions.
} 
customers procure scientific information for research conducted at the post-collegiate level. Over the past 15 years at the INL, staff education levels have remained at a consistent, high-level - particularly within the research community.

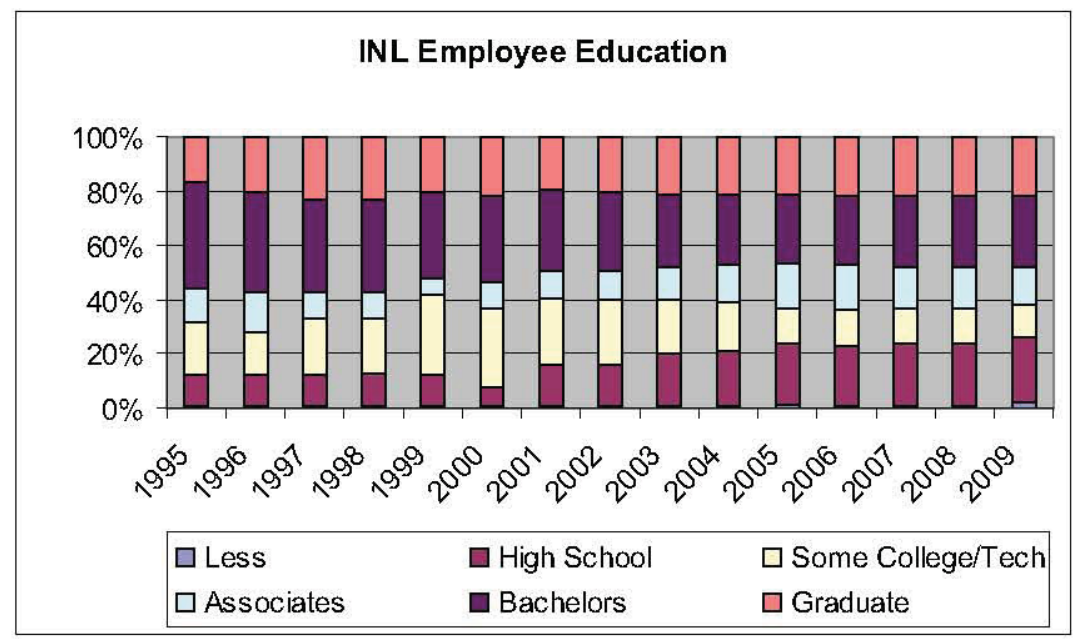

Figure 4-1. Total INL Employee Education. Bachelors and Graduate degrees represent the predominant research sectors of the Laboratory.

Another aspect of calculating intellectual output that has been a challenge to measure is the middle factor of the user and his ability to understand and process the information given. According to Jennifer Cram:

One of the difficulties in attempting to measure the value of a library is the near impossibility of measuring its intellectual output, because that is wholly dependent on the proportionate intellectual input of the library user. For example, the library acquires published information - intellectual output of authors and publishers. Then it might enhance the publication or information by organizing and possibly analyzing it. When the library hands the publication or information to a customer, that customer in turn adds value by evaluating the information presented in the context of his or her personal knowledge, experience and judgment. ${ }^{44}$

With a highly-educated employee population, the INL scientific community is well equipped to process background information for research projects. INL employees are trained to process information efficiently because of their academic backgrounds in research. Because the educational community is highly educated and education rates have remained consistent over the past 15 years, this intermediary factor will be considered constant and the library and INL output will be considered ceteris paribus.

\subsubsection{Output: Intellectual Capital}

For the purposes of this study INL output is divided into invention disclosures, cooperative research and development agreements, publications, patents and spin-off company outputs. These categories are considered the innovation products of research projects at the INL. Each of these categories is supported by INL Research Library information research services. These five variables represent the intellectual property generated at the INL.

\footnotetext{
44 Jennifer Cram, "Six impossible Things Before Breakfast. A Multidimensional Approach to Measuring the Value of Libraries," Proceedings of the 3rd Northumbria International Conference on Performance Measurement in Libraries and Information Services (1999):19-29.
} 


\subsection{Calculation Method and Results}

For the assessment of intellectual value creation, data on the INL was collected from a series of sectors within the organization. Most data was collected from management and information resources including previous studies, such as INL impact reports from 1995-2001, INL benchmarking output study for 2002-2007 and annual internal library studies.

\subsubsection{Regression analysis}

Before completing a regression analysis of the various input and output variables, each variable was multiplied by a fraction representing its estimated monetary value (see Appendix A-4.1 and A-4.2. Thus all the variables had the same base unit, allowing for a total input/output value of the study to be calculated. These overall values were what were used for calculating the regression.

The first regression between these straight total values, using library services calculated as "input," were used as the independent variable and INL intellectual productivity variables were used as "output," the dependent variable. The first regression resulted in a highly uncorrelated relation, resulting in $\mathrm{R}^{2}=0.02077$. However, upon further inspection of the data, a pattern emerged. Both sets of data strongly correlated with third-degree polynomial curves, at $\mathrm{R}^{2}=0.771$ and $\mathrm{R}^{2}=0.8626$ respectfully (see Figure 4-2).

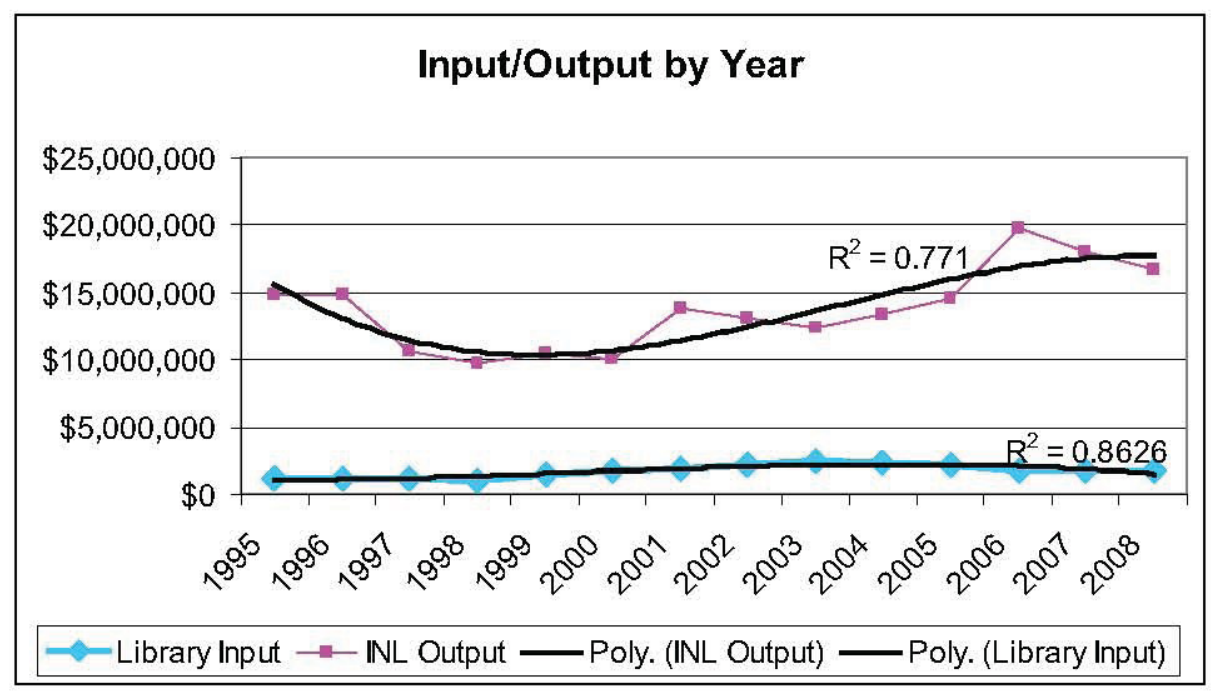

Figure 4-2. Input/output comparison by year with third-degree polynomial function treads.

This general curvature of both data sets, independently, suggests a possible relationship between the two, with different maxima and minima for each associated function. By calculating the maxima, minima and inflection point of each curve, it was revealed that the two curves were even more related. There was an average 3.69 year shift between each critical point on the input and output curves (with a 0.01 marginal error). This suggests a relationship between library services and researcher intellectual output; however, there exists a time delay of approximately 3.69 years between the use of library resources and measureable intellectual output. Interestingly, based on researcher interviews, the average project life at the INL is approximately three to four years, further supporting a time-delay correlation between library services and organizational intellectual output.

Because data was collected for each year and not divided into shorter time periods, the data was shifted four years. This shift paired 1995 library data with the 1999 INL output data. After the time shift 
was made, only 10 observations were available for study. The regression showed a $R^{2}=0.744$, a much stronger correlation between library input and INL output (see Figure 4-3). This further emphasizes the existence of a time delay between library input and intellectual output.

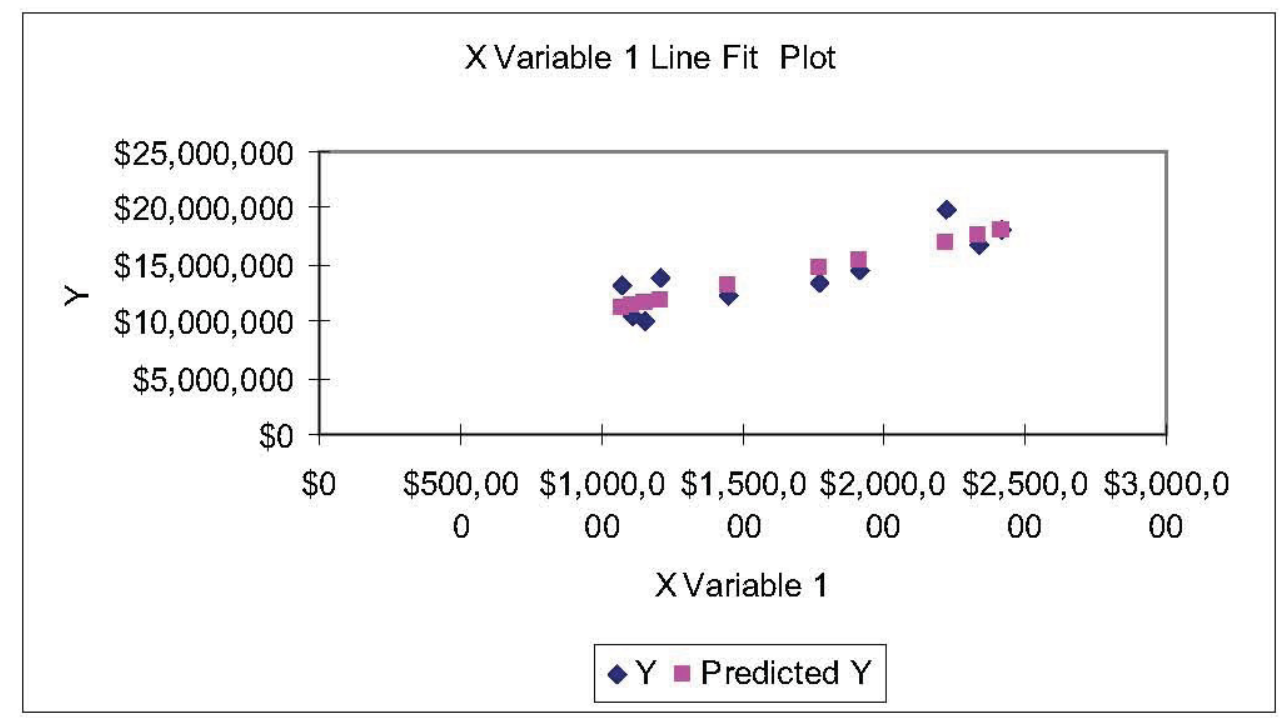

Figure 4-3. Line fit plot of shifted library input (X) to INL output (Y).

With this time shift, there appears to be a strong relationship between library services and total INL intellectual output, reflecting the time needed to transform information into innovation through scientific discovery.

\subsubsection{Intellectual Value Model}

Due to the methods used to collect data for this study, no controlled experiments were conducted. Verification of the correlation between library input and INL intellectual output would require future data collection to suggested relationship by the regression. For this model, we assumed that a direct relationship between library services and INL output has been established. We assume this for the following reasons:

- Most research conducted at INL requires extensive scientific background research on a topic being investigated.

- Most INL scientists and engineers use the library's resources to help maximize research findings.

- The library user's educational profile at INL has not changed over the past fifteen years. This factor is considered statistically constant and becomes insignificant after differentiation.

However in a community environment, education growth/decline would be a multiplication factors that needed to be included in a model. Therefore by accepting this relationship, we observe the following.

Assume: $\quad f(t)=$ Best approximated line (slope-intercept) for INL output

$$
\begin{aligned}
g(t-2)= & \text { Best approximated line (slope-intercept) for library services } \\
h(t-2)= & \text { Best approximated line (slope-intercept) for library budget } \\
\mathrm{j}(\mathrm{t}-2)= & \text { Best approximated line (slope-intercept) for education growth of an } \\
& \text { organization's research force or a community's user profile }
\end{aligned}
$$



$2=$ time delay of research completion
$\mathrm{t}=$ time in years
$\alpha=$ intellectual value multiplication factor
$\vartheta=$ education multiplication factor (assume $1 \leq \vartheta \geq 10$ to determine importance of a specific educational background in information application)

a) $\partial \mathrm{f}(\mathrm{t}) /(\partial \mathrm{g}(\mathrm{t}-\mathrm{Z}) *(1+\vartheta * \partial \mathrm{j}(\mathrm{t}-\mathrm{Z})))=\mathrm{A}=$ approximated rate of $\$$ created from INL output per $\$$ of library service distributed

b) $\partial \mathrm{f}(\mathrm{t}) / \partial \mathrm{h}(\mathrm{t}-\mathrm{C})=\mathrm{B}=\mathrm{INL}$ output to INL library budget ratio

c) $(\partial \mathrm{f}(\mathrm{t}) / \partial \mathrm{h}(\mathrm{t}-\mathrm{2})) *((\partial \mathrm{g}(\mathrm{t}-\mathrm{e}) *(1+\vartheta * \partial \mathrm{j}(\mathrm{t}-2))) / \partial \mathrm{f}(\mathrm{t}))$

$=\underline{(\partial \mathrm{g}(\mathrm{t}-2) *(1+\vartheta * \partial \mathrm{j}(\mathrm{t}-2)))}$

$\partial \mathrm{h}(\mathrm{t}-\mathrm{e})$

$=\mathrm{C}=$ Knowledge Management Productivity multiplier

a) $(\partial \mathrm{f}(\mathrm{t}) /(\partial \mathrm{g}(\mathrm{t}-\mathrm{C}) *(1+\vartheta * \partial \mathrm{j}(\mathrm{t}-\mathrm{2})))-((\partial \mathrm{g}(\mathrm{t}-\mathrm{2}) *(1+\vartheta * \partial \mathrm{j}(\mathrm{t}-2))) / \partial \mathrm{h}(\mathrm{t}-$ 2))

$=\mathrm{D}=$ Intellectual Productivity multiplier

a) $\alpha=\mathrm{C} * \mathrm{D}=$ total intellectual value of materials a priori.

The final calculations of these models will reveal if economic growth is occurring. If the answers to equations a through $d$ are less than or equal to one ([A,D] $\leq 1)$, no return is being made on the library investment. If equations a through $\mathrm{d}$ are greater than one $([\mathrm{A}, \mathrm{D}]>1)$, returns are being made in the specific section of the information cycle that the equation represents. If $\sum$ of $[A, D] \gg 1$, then significant returns are being made throughout the entire cycle, and all applications related to the library are economically efficient.

\subsection{Final Data Results}

For the INL Research Library, these methods were applied and the following calculations and estimations were made to assess the Library's direct impact on Laboratory performance.

Assume: $\quad f(t)=893,466(t)+9,000,000$

$$
\begin{aligned}
& \mathrm{g}(\mathrm{t}-2)=168,465(\mathrm{t}-2)+740,169 \\
& \mathrm{~h}(\mathrm{t}-2)=83,508(\mathrm{t}-2)+2,000,000 \\
& \mathrm{j}(\mathrm{t}-2)=\mathrm{C}^{45} \\
& \mathrm{2}=4 \text { years } \\
& \mathrm{t}=[1999,2008]
\end{aligned}
$$

\footnotetext{
${ }^{45}$ Note: $\partial \mathrm{j}(\mathrm{t} \quad \varepsilon)=0$ because $\mathrm{j}(\mathrm{t} \quad \mathcal{\varepsilon})$ is a constant. Thus, $1+\vartheta \times \partial \mathrm{j}(\mathrm{t}-\boldsymbol{\varepsilon})=1$. As a multiplication factor for this study, it falls out and is considered insignificant for $\mathbb{N L}$.
} 
$\vartheta=10$ (educational background importance is maximized at INL)

a) $\partial \mathrm{f}(\mathrm{t}) /(\partial \mathrm{g}(\mathrm{t}-\mathrm{2}) *(1+10 * \partial \mathrm{j}(\mathrm{t}-\mathrm{2})))=\$ 5.30$

b) $\partial \mathrm{f}(\mathrm{t}) / \partial \mathrm{h}(\mathrm{t}-\mathrm{2})=\$ 10.70^{46}$

c) $(\partial \mathrm{g}(\mathrm{t}-2) *(1+10 * \partial \mathrm{j}(\mathrm{t}-2)))$

$\partial \mathrm{h}(\mathrm{t}-\mathrm{e})$

$=\$ 2.02$

a) $(\partial \mathrm{f}(\mathrm{t}) /(\partial \mathrm{g}(\mathrm{t}-\mathrm{2}))-(\partial \mathrm{g}(\mathrm{t}-\mathrm{2}) / \partial \mathrm{h}(\mathrm{t}-\mathrm{2}))=\$ 3.28$

b) $\alpha=\mathrm{C} * \mathrm{D}=\$ 6.63$

Thus, from data analysis, it can be concluded that the INL Research Library provides valuable research services and generates intellectual value for the INL. This is accomplished in two ways. First from knowledge management productivity, INL librarians increase the value of resources collected by a factor of 2.02. (This value is an average estimate of the total trend of spending versus output from 19952008.) Second from intellectual productivity, INL scientists increase the value of information by a factor of 3.28 .

In the mathematical model the value of $\alpha$ is $\$ 6.63$, which represents the value of information serviced by the library to the scientist a priori. As noted above, this means that for every $\$ 1$ of information the library inputs into the research sector of INL, it generates $\$ 6.63$ in intellectual value that goes to form intellectual property (innovation) (see appendix B). By applying this multiplier to the total financial assets of the library, an estimated intellectual value of the library's hard assets is assessed. Thus, the estimated value of the library's information material collection a priori to the Laboratory in innovation is $\$ 614,616,015$.

True values of annual estimates should fluctuate around these estimates. To maximize the value of generated output, more training classes for more accessible internet based library services and more highly trained research staff to increase the caliber of services provided to INL scientists and engineers should be considered.

\subsection{Error}

In the calculation of INL output, our main goal was to capture the average rate at which output was growing using the five measures chosen. There are other variables, such as copyright royalties, general licensing agreements and work-for-others funding that also generates output for the INL and is significant to the INL's mission. Likewise, in the calculation of INL Research Library input, other factors were not considered such as electronic communication services (routing transactions, photocopies), technical support activities (publication, materials management), and responsiveness (averaging 94\%).

In the creation of the model, the decision to exclude the factor of the user variability was due to the consistent education levels of users. The obvious impact from a user perspective is how users interpret research information crucial to the development of the five output factors mentioned, yet education level over the past 15 years at INL has stayed consistent, varying within the margin of error. Although this model only relies upon quantified data and does not include dummy variables, other qualitative factors could have been overlooked that relate to the user but are not captured in data recorded by the INL.

\footnotetext{
${ }^{46}$ The final product of intellectual property doubles in value in its final stage from the actual generation of a new idea from human capital input. This is not related to library services and thus not studied in this report.
} 


\section{CONCLUSION}

As communities try to cut back on costs due to challenging economic times, libraries are being affected - hindering the intellectual growth of the population. Yet libraries are a key component for promoting economic growth within a community. Assessing the value of a library, on both a financial and an intellectual level, is central to proving this importance; but previous models fail to provide a short, simple analytical method for assessing the impact of a library. In this study, we have provided methods for estimating the financial value of a library's assets and a method of estimating the intellectual value a library gives to a larger organization. All methods were tested using the INL and the INL Research Library.

The financial value of the Research Library's hard assets was estimated to be worth $\$ 93,620,109$, excluding irreplaceable and electronic resources. The intellectual value created by the library's services was estimated to be approximately $\$ 2.02$ for every dollar spent investing in the library. Combined with the economic value of information to scientists for research, it is estimated that every dollar of input from the library, approximated $\$ 6.63$ is created in INL intellectual property (output), between information/services issued and intellectual application. This means that the addition of library services increases information value in output by $62 \%$. With the discovery of a multiplication factor specifically for INL, the estimated worth of the library's collection to INL is $\$ 614,616,015$ in economic value (opportunity cost). By applying analytical methods to data collected from within the INL community, we have concluded that the library is as a positive economic factor for the INL and the wider community. 


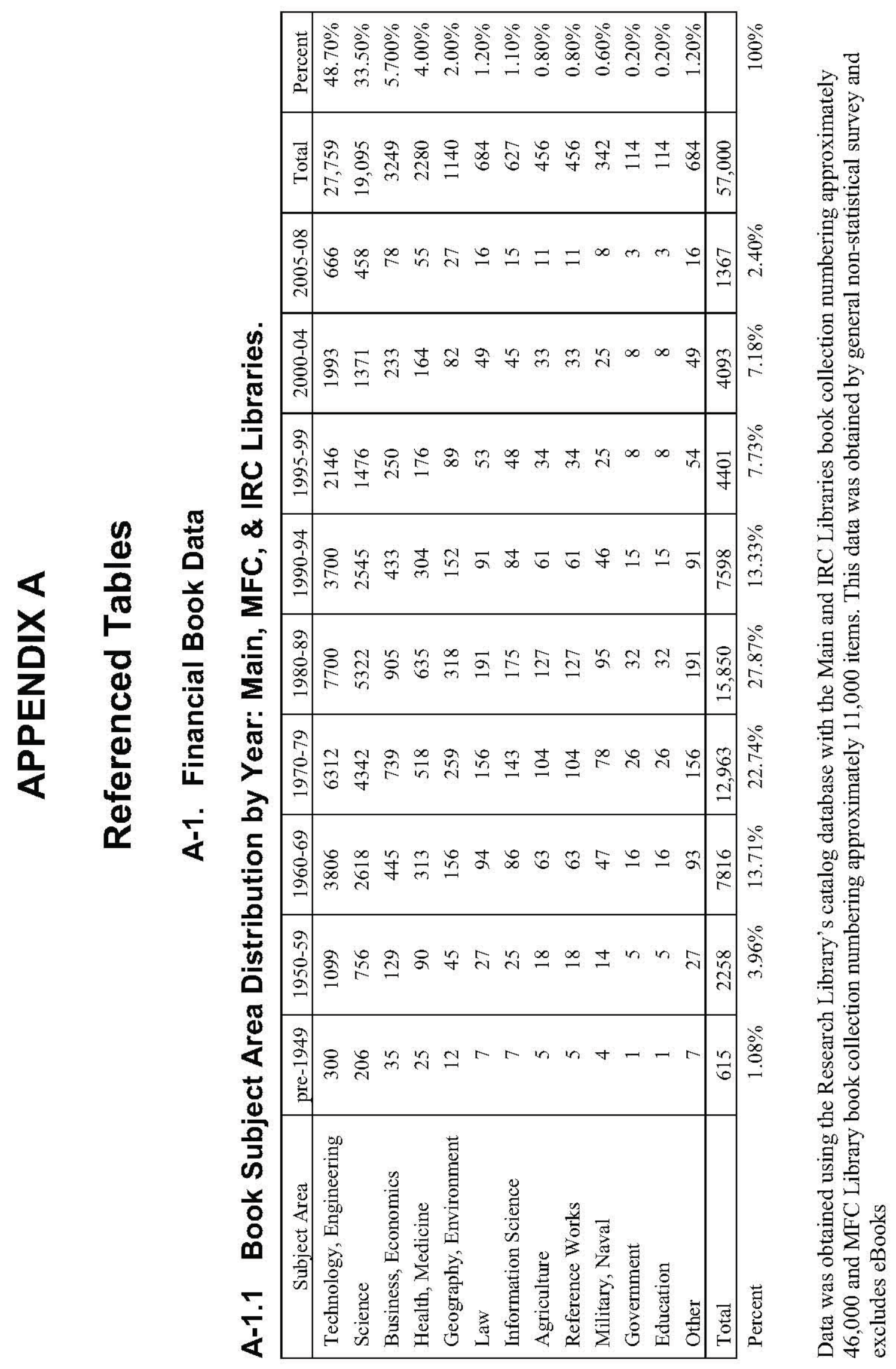




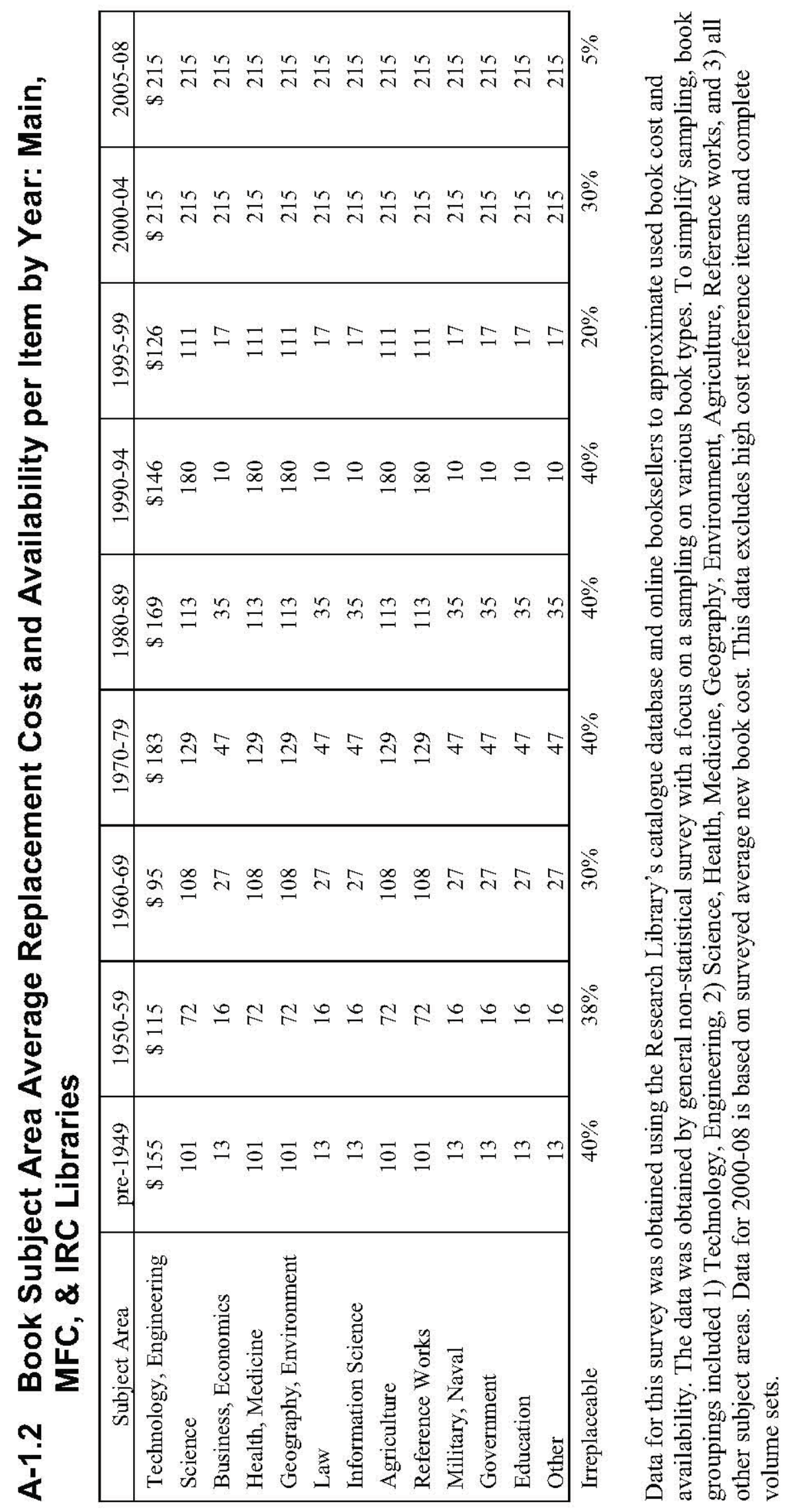




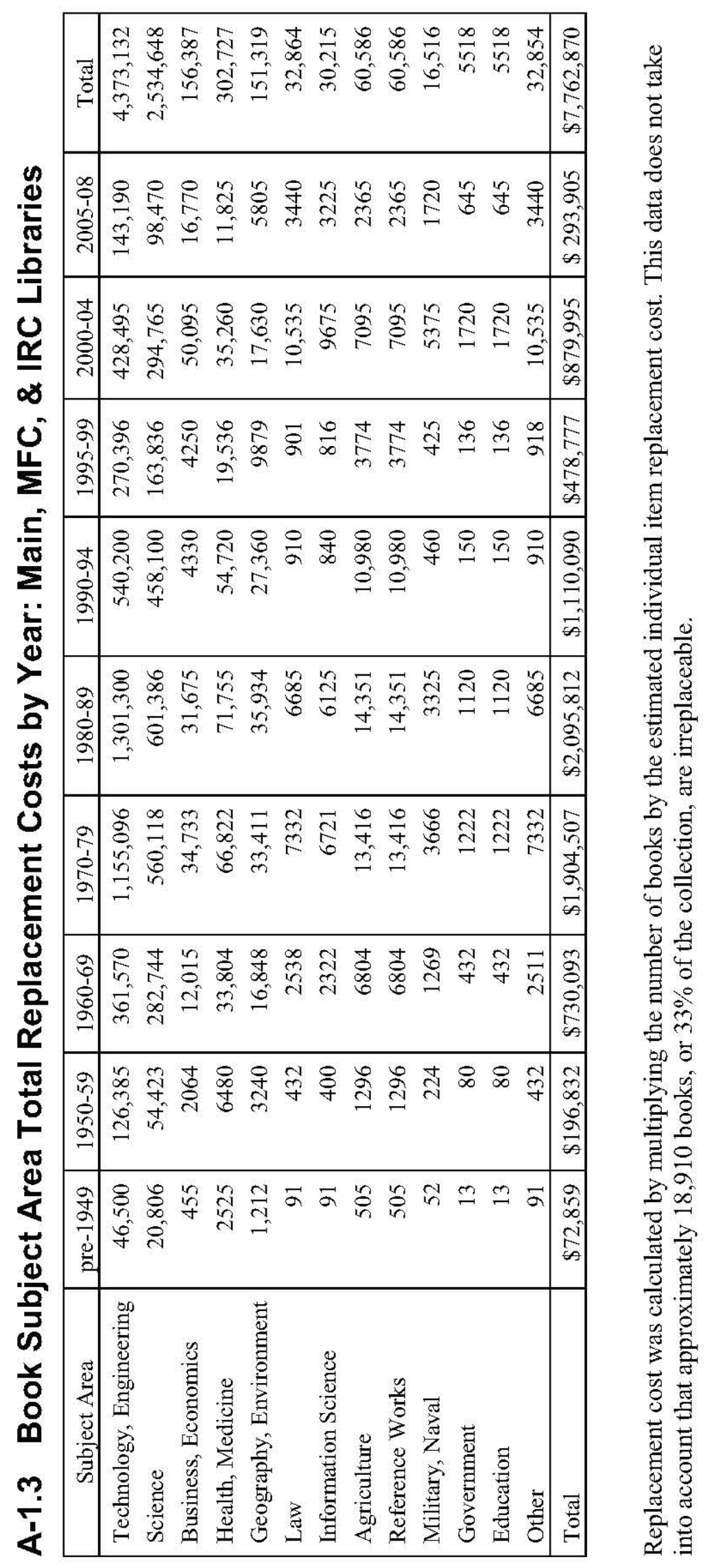




\section{A-2. Financial Report Data}

\section{A-2.1 Microfiche and Microcard, Main Library}

\begin{tabular}{|c|c|c|}
\hline Subject Area & Number & Percent \\
\hline Batteries and Components & 4992 & $0.52 \%$ \\
\hline Ceramics, Refractories, and Glasses & 12,480 & $1.30 \%$ \\
\hline Composite Materials & 22,944 & $2.39 \%$ \\
\hline Corrosion and Corrosion Inhibition & 5760 & $0.60 \%$ \\
\hline Environmental Engineering & 384 & $0.04 \%$ \\
\hline Environmental Safety and Health & 59,328 & $6.18 \%$ \\
\hline Environmental Studies & 15072 & $1.57 \%$ \\
\hline Fluid Mechanics & 61,344 & $6.39 \%$ \\
\hline Geology and Geophysics & 18,240 & $1.90 \%$ \\
\hline Hydrology and Limnology & 40,992 & $4.27 \%$ \\
\hline Industrial Safety Engineering & 4416 & $0.46 \%$ \\
\hline Iron and Iron Alloys & 7296 & $0.76 \%$ \\
\hline Isotopes & 11,136 & $1.16 \%$ \\
\hline Materials Degradation and Fouling & 5760 & $0.60 \%$ \\
\hline Microbiology & 38,304 & $3.99 \%$ \\
\hline Nonferrous Metals and Alloys & 23,712 & $2.47 \%$ \\
\hline Nuclear Auxiliary Power Systems & 1344 & $0.14 \%$ \\
\hline Nuclear Instrumentation & 19,200 & $2.00 \%$ \\
\hline Nuclear Propulsion & 1056 & $0.11 \%$ \\
\hline Photochemistry and Radiation Chemistry & 4032 & $0.42 \%$ \\
\hline Policies, Regulations, and Studies & 27,840 & $2.90 \%$ \\
\hline Radiation, Shielding, Protection, and Safety & 106,176 & $11.06 \%$ \\
\hline Radioactive Wastes and Radioactivity & 262,080 & $27.30 \%$ \\
\hline Radiobiology & 29,760 & $3.10 \%$ \\
\hline Reactor Engineering and Nuclear Power Plants & 97,920 & $10.20 \%$ \\
\hline Reactor Fuels and Fuel Processing & 37,824 & $3.94 \%$ \\
\hline Reactor Materials & 4608 & $0.48 \%$ \\
\hline Reactor Physics & 7296 & $0.76 \%$ \\
\hline Selected Studies in Nuclear Technology & 14,880 & $1.55 \%$ \\
\hline Soil and Rock Mechanics & 7776 & $0.81 \%$ \\
\hline Soil Sciences & 6048 & $0.63 \%$ \\
\hline Total & 960,000 & $100.00 \%$ \\
\hline
\end{tabular}




\section{A-2.2 Hardcopy and eReports, Main Library}

\begin{tabular}{|l|r|r|}
\hline \multicolumn{1}{|c|}{ Originator/Media } & Number & Percent \\
\hline Idaho National Laboratory - Hardcopy & 37,000 & $13.63 \%$ \\
Idaho National Laboratory - Historical (SL-1, etc.) & 200 & $0.08 \%$ \\
Other (DOE, NASA, Commercial, etc.) - Hardcopy & 233,000 & $85.85 \%$ \\
eReports & 1200 & $0.44 \%$ \\
\hline Total & 271,400 & $100 \%$ \\
\hline
\end{tabular}

\section{A-2.3 Reports, MFC Library}

\begin{tabular}{|l|r|r|}
\hline \multicolumn{1}{|c|}{ Originator/Media } & Number & Percent \\
\hline Idaho National Laboratory - Hardcopy & 7,000 & $3.70 \%$ \\
Other (DOE, NASA, Commercial, etc.) - Hardcopy & 10,700 & $5.70 \%$ \\
Microfiche & 170,000 & $90.60 \%$ \\
\hline Total & 187,700 & $100 \%$ \\
\hline
\end{tabular}

\section{A-3. Financial Journal Data}

\section{A-3.1 Weighted Sample Size by Journal Subject Area: Main, MFC, \& IRC Libraries}

\begin{tabular}{|l|c|c|c|c|}
\hline \multicolumn{1}{|c|}{ Subject Area: } & Total & \%of total & $\begin{array}{c}\text { Sample Size } \\
(5 \%)\end{array}$ & $\begin{array}{c}\text { Corrected } \\
(\% 5)\end{array}$ \\
\hline & $\mathrm{x}$ & $\mathrm{x} / 1,889$ & $\mathrm{x} /\left(1+\mathrm{x}^{*}\left(0.05^{\wedge} 2\right)\right)$ & $(\mathrm{x} / 1889)^{*} \mathrm{SCC}$ \\
Agriculture & 72 & 0.0381 & 61 & 11 \\
Arts and Social Sciences & 34 & 0.0180 & 31 & 5 \\
Biology (Biotechnology) & 31 & 0.0164 & 29 & 5 \\
Business/Management Science & 52 & 0.0275 & 46 & 8 \\
Chemistry & 469 & 0.2483 & 216 & 74 \\
Computer Science & 17 & 0.0090 & 16 & 3 \\
Energy & 46 & 0.0244 & 41 & 7 \\
Engineering and Technology & 340 & 0.1800 & 184 & 54 \\
Environmental Science & 61 & 0.0323 & 53 & 10 \\
Geology and Earth Science & 76 & 0.0402 & 64 & 12 \\
Health and Safety & 23 & 0.0122 & 22 & 4 \\
Information Sciences & 93 & 0.0492 & 75 & 7 \\
Instrumentation & 43 & 0.0228 & 39 & 18 \\
Material Science & 116 & 0.0614 & 90 & 8 \\
Mathematics and Statistics & 51 & 0.0270 & 45 & 24 \\
Nuclear Science and Technology & 151 & 0.0799 & 110 & 27 \\
Physics & 170 & 0.0900 & 119 & 7 \\
Other: Law, Library Sciences & 44 & 0.0233 & 40 & 300 \\
\hline Total population size: & 1,889 & 1.0000 & 330 & \\
\hline
\end{tabular}




\section{A-3.2 Depreciation Data and Averaged Factors}

\begin{tabular}{|c|c|c|c|c|c|}
\hline Year & Sample 1 & Sample 2 & Sample 3 & Averages & Decade Average \\
\hline 1965 & 0.15 & 0.3 & 0.28 & 0.243333 & 0.243333333 \\
\hline 1966 & 0.15 & 0.3 & 0.28 & 0.243333 & \\
\hline 1967 & 0.15 & 0.3 & 0.28 & 0.243333 & \\
\hline 1968 & 0.15 & 0.3 & 0.28 & 0.243333 & \\
\hline 1969 & 0.15 & 0.3 & 0.28 & 0.243333 & \\
\hline 1970 & 0.15 & 0.3 & 0.366 & 0.272 & 0.303923077 \\
\hline 1971 & 0.25641 & 0.3 & 0.366 & 0.30747 & \\
\hline 1972 & 0.25641 & 0.3 & 0.366 & 0.30747 & \\
\hline 1973 & 0.25641 & 0.3 & 0.366 & 0.30747 & \\
\hline 1974 & 0.25641 & 0.3 & 0.366 & 0.30747 & \\
\hline 1975 & 0.25641 & 0.3 & 0.366 & 0.30747 & \\
\hline 1976 & 0.25641 & 0.3 & 0.366 & 0.30747 & \\
\hline 1977 & 0.25641 & 0.3 & 0.366 & 0.30747 & \\
\hline 1978 & 0.25641 & 0.3 & 0.366 & 0.30747 & \\
\hline 1979 & 0.25641 & 0.3 & 0.366 & 0.30747 & \\
\hline 1980 & 0.25641 & 0.3 & 0.366 & 0.30747 & 0.407203419 \\
\hline 1981 & 0.25641 & 0.3 & 0.366 & 0.30747 & \\
\hline 1982 & 0.25641 & 0.56 & 0.48 & 0.432137 & \\
\hline 1983 & 0.25641 & 0.56 & 0.48 & 0.432137 & \\
\hline 1984 & 0.25641 & 0.56 & 0.48 & 0.432137 & \\
\hline 1985 & 0.25641 & 0.56 & 0.48 & 0.432137 & \\
\hline 1986 & 0.25641 & 0.56 & 0.48 & 0.432137 & \\
\hline 1987 & 0.25641 & 0.56 & 0.48 & 0.432137 & \\
\hline 1988 & 0.25641 & 0.56 & 0.48 & 0.432137 & \\
\hline 1989 & 0.25641 & 0.56 & 0.48 & 0.432137 & \\
\hline 1990 & 0.25641 & 0.56 & 0.48 & 0.432137 & 0.537871795 \\
\hline 1991 & 0.25641 & 0.77 & 0.48 & 0.502137 & \\
\hline 1992 & 0.25641 & 0.77 & 0.48 & 0.502137 & \\
\hline 1993 & 0.25641 & 0.77 & 0.48 & 0.502137 & \\
\hline 1994 & 0.25641 & 0.77 & 0.48 & 0.502137 & \\
\hline 1995 & 0.25641 & 0.77 & 0.48 & 0.502137 & \\
\hline 1996 & 0.25641 & 0.77 & 0.48 & 0.502137 & \\
\hline 1997 & 0.683761 & 0.77 & 0.48 & 0.644587 & \\
\hline 1998 & 0.683761 & 0.77 & 0.48 & 0.644587 & \\
\hline 1999 & 0.683761 & 0.77 & 0.48 & 0.644587 & \\
\hline
\end{tabular}




\begin{tabular}{|c|c|c|c|c|c|}
\hline Year & Sample 1 & Sample 2 & Sample 3 & Averages & Decade Average \\
\hline 2000 & 0.722222 & 0.77 & 0.48 & 0.657407 & 0.745868946 \\
2001 & 0.726496 & 0.77 & 0.48 & 0.658832 & \\
2002 & 0.747863 & 0.77 & 0.48 & 0.665954 & \\
2003 & 0.811966 & 0.77 & 0.48 & 0.687322 & \\
2004 & 0.854701 & 0.77 & 0.48 & 0.701567 & \\
2005 & 0.888889 & 0.98 & 0.48 & 0.782963 & \\
2006 & 0.901709 & 0.98 & 0.48 & 0.787236 & \\
2007 & 0.923077 & 0.98 & 0.48 & 0.794359 & \\
2008 & 0.961538 & 1 & 0.97 & 0.977179 & \\
2009 & 1 & 1 & 1 & 1 & \\
\hline
\end{tabular}

Sources for this sample for price changes were from the following journals and major publishers.

- Sample 1: Annual Review of Materials Research from Wiley InterScience Publications.

- Sample 2: Accounting, Auditing and Accountability Journal from Emerald Publishing.

- Sample 3: SIAM Journal of Mathematics from the Society for Industrial and Applied Mathematics.

Percentages represent the percent which the publisher is selling back volumes of each particular journal in comparison to its present subscription price (2009). Fractions were averaged for each year from 1965 to 2009 , and then averaged for each decade. Highlighted values in the far right column represent the average depreciation value that was used in this study. Only the first three digits were used in the calculation of each journal datum point's overall value in the INL Research Library's collection. 


\section{A-3.3 Depreciation Data and Averaged Factors}

\begin{tabular}{|c|c|c|c|c|c|}
\hline Subject Area & Number & $\begin{array}{c}\text { Percent } \\
(\%)\end{array}$ & Sample & $\begin{array}{c}\text { Total Cost } \\
\text { (\$) }\end{array}$ & $\begin{array}{r}\text { Total Cost } \\
\text { (print only) } \\
\text { (\$) }\end{array}$ \\
\hline Agriculture & 72 & 3.81 & 11 & 148,812 & 137,756 \\
\hline Arts and Social Sciences & 34 & 1.80 & 5 & 92,733 & 92,716 \\
\hline Biology (Biotechnology) & 31 & 1.64 & 5 & 150,053 & 144,963 \\
\hline Business/Management Science & 52 & 2.75 & 8 & 171,246 & 146,105 \\
\hline Chemistry & 469 & 24.83 & 74 & $2,303,974$ & $1,761,022$ \\
\hline Computer Science & 17 & 0.90 & 3 & 6,238 & 6,238 \\
\hline Energy & 46 & 2.44 & 7 & 14,921 & 14,921 \\
\hline Engineering and Technology & 340 & 18.00 & 54 & 971,759 & 800,783 \\
\hline Environmental Science & 62 & 3.28 & 10 & 35,173 & 33,170 \\
\hline Geology and Earth Science & 76 & 4.02 & 12 & 443,653 & 381,319 \\
\hline Health and Safety & 23 & 1.22 & 4 & 33,179 & 27,447 \\
\hline Information Sciences & 93 & 4.92 & 15 & 280,137 & 248,636 \\
\hline Instrumentation & 43 & 2.28 & 7 & 78,444 & 62,168 \\
\hline Material Science & 116 & 6.14 & 18 & 265,836 & 230,825 \\
\hline Mathematics and Statistics & 51 & 2.70 & 8 & 285,807 & 260,232 \\
\hline Nuclear Science and Technology & 150 & 7.94 & 24 & 654,230 & 571,766 \\
\hline Physics & 170 & 9.00 & 27 & 677,550 & 550,293 \\
\hline Other: Law, Library Sciences & 44 & 2.33 & 7 & 7,990 & 4,380 \\
\hline Total: & 1,889 & 100.00 & 300 & & \\
\hline
\end{tabular}

\begin{tabular}{|l|l|r|r|}
\hline Sample total: & (the sum of the subject areas) & $6,621,733$ & $5,474,740$ \\
Average journal cost: & (sample total/sample size) & 22,072 & 18,249 \\
Total journal value: & (average journal cost*Journal\#) & $41,694,847$ & $34,472,610$ \\
Online journal value: & ((total print + online)-total print) & $7,222,237$ & 0 \\
\hline Estimated Error (5\%): & (total journal value*0.05) & $2,084,742$ & $1,723,631$ \\
\hline
\end{tabular}




\section{A-4. Intellectual Data}

\section{A-4.1 Input/Output Data Collected as Measuring Factors on INL}

\begin{tabular}{l|crrrr|}
\multicolumn{1}{c}{ Library Input } & \multicolumn{1}{c|}{ ILL } & Service & $\begin{array}{c}\text { Publication } \\
\text { Spending }\end{array}$ \\
\cline { 2 - 6 } & Training & Computer & 3,110 & 23,205 & $\$ 563,870$ \\
1995 & 50 & 99,768 & 2,945 & 18,845 & $\$ 611,196$ \\
1996 & 50 & 175,330 & 2,772 & 17,575 & $\$ 742,515$ \\
1997 & 50 & 114,012 & 2,963 & 17,932 & $\$ 660,710$ \\
1998 & 50 & 58,356 & 2,877 & 18,428 & $\$ 879,968$ \\
1999 & 50 & 203,976 & 2,772 & 15,072 & $\$ 1,133,471$ \\
2000 & 100 & 325,884 & 2,590 & 18,228 & $\$ 1,306,417$ \\
2001 & 200 & 254,028 & 2,920 & 14,527 & $\$ 1,475,030$ \\
2002 & 400 & 426,528 & 2,639 & 13,388 & $\$ 1,525,599$ \\
2003 & 300 & 597,852 & 2,257 & 10,556 & $\$ 1,654,732$ \\
2004 & 300 & 443,736 & 1,997 & 11,495 & $\$ 1,477,503$ \\
2005 & 100 & 420,231 & 2,075 & 5,778 & $\$ 1,099,600$ \\
2006 & 100 & 490,539 & 2,820 & 6,800 & $\$ 1,101,435$ \\
2007 & 200 & 455,856 & 3,580 & 9,400 & $\$ 1,007,811$ \\
2008 & 200 & 473,198 & & &
\end{tabular}

INL Output

\begin{tabular}{l|rrrrr|}
\multicolumn{1}{c}{ INL Output } & IDR & Patents & \multicolumn{1}{c|}{ Spin-Off } & Publications \\
\cline { 2 - 6 } 1995 & CRADAs & 116 & 10 & $\$ 8,380,000$ & 315 \\
\cline { 2 - 6 } 1996 & 20 & 119 & 12 & $\$ 16,538,000$ & 219 \\
1997 & 20 & 114 & 125 & $\$ 21,078,000$ & 183 \\
1998 & 11 & 123 & 130 & $\$ 31,050,000$ & 156 \\
1999 & 7 & 119 & $\$ 34,050,000$ & 228 \\
2000 & 7 & 128 & $\$ 34,050,000$ & 154 \\
2001 & 7 & 121 & 175 & $\$ 39,426,315$ & 165 \\
2002 & 13 & 162 & 87 & $\$ 43,010,525$ & 268 \\
2003 & 9 & 126 & 160 & $\$ 43,010,525$ & 237 \\
2004 & 9 & 120 & $\$ 43,010,525$ & 227 \\
2005 & 15 & 110 & 96 & $\$ 48,386,840$ & 375 \\
2006 & 10 & 77 & 38 & $\$ 48,386,840$ & 337 \\
2007 & 19 & 118 & $\$ 50,178,945$ & 394 \\
2008 & 15 & 83 & & & 349 \\
\end{tabular}




\section{A-4.2 INL Input/Output Data Changed to Units of U.S.D.}

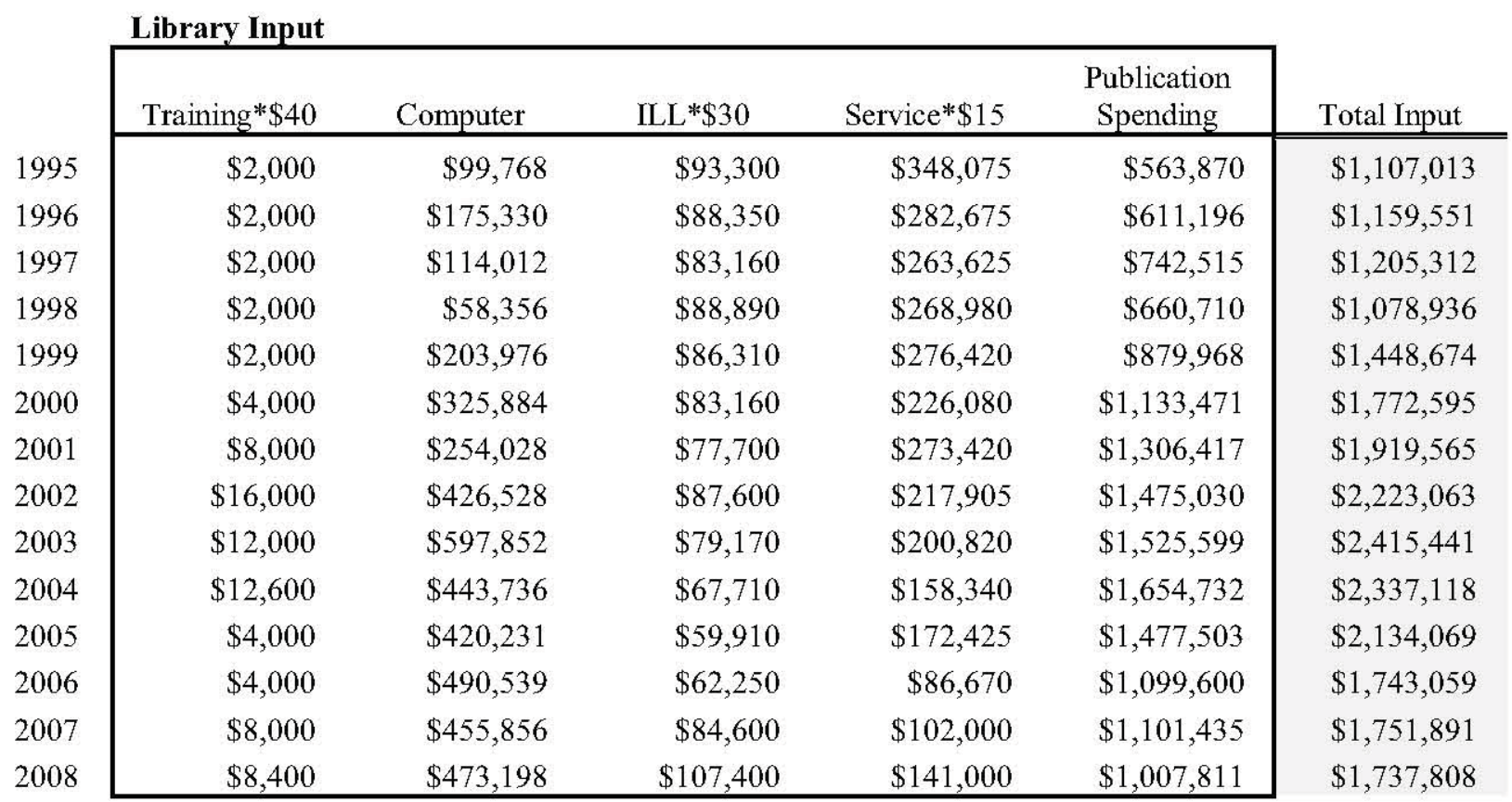

\begin{tabular}{l|rrrrr|r}
\multicolumn{1}{c}{} & INL Output \\
\cline { 2 - 5 } & \multicolumn{1}{c}{ CRADAs } & \multicolumn{1}{c}{ IDR } & \multicolumn{1}{c}{ Patents } & \multicolumn{1}{c}{ Spin-Off } & Publications & Total Output \\
\cline { 2 - 6 } 1995 & $\$ 9,562,913$ & $\$ 1,163,333$ & $\$ 177,360$ & $\$ 8,380,000$ & $\$ 3,150,000$ & $\$ 14,891,606$ \\
1996 & $\$ 9,562,913$ & $\$ 1,186,667$ & $\$ 212,832$ & $\$ 16,538,000$ & $\$ 2,190,000$ & $\$ 14,806,211$ \\
1997 & $\$ 5,259,602$ & $\$ 1,140,000$ & $\$ 248,304$ & $\$ 21,078,000$ & $\$ 1,830,000$ & $\$ 10,585,706$ \\
1998 & $\$ 3,347,019$ & $\$ 1,230,000$ & $\$ 478,872$ & $\$ 31,050,000$ & $\$ 1,560,000$ & $\$ 9,720,891$ \\
1999 & $\$ 3,347,019$ & $\$ 1,120,000$ & $\$ 354,720$ & $\$ 34,050,000$ & $\$ 2,280,000$ & $\$ 10,506,739$ \\
2000 & $\$ 3,347,019$ & $\$ 1,210,000$ & $\$ 478,872$ & $\$ 34,050,000$ & $\$ 1,540,000$ & $\$ 9,980,891$ \\
2001 & $\$ 6,215,893$ & $\$ 1,620,000$ & $\$ 407,928$ & $\$ 39,426,315$ & $\$ 1,650,000$ & $\$ 13,836,453$ \\
2002 & $\$ 4,303,311$ & $\$ 1,260,000$ & $\$ 514,344$ & $\$ 43,010,525$ & $\$ 2,680,000$ & $\$ 13,058,707$ \\
2003 & $\$ 4,303,311$ & $\$ 780,000$ & $\$ 532,080$ & $\$ 43,010,525$ & $\$ 2,370,000$ & $\$ 12,286,443$ \\
2004 & $\$ 4,781,456$ & $\$ 1,500,000$ & $\$ 461,136$ & $\$ 43,010,525$ & $\$ 2,270,000$ & $\$ 13,313,645$ \\
2005 & $\$ 4,781,456$ & $\$ 1,100,000$ & $\$ 549,816$ & $\$ 43,010,525$ & $\$ 3,750,000$ & $\$ 14,482,325$ \\
2006 & $\$ 9,084,767$ & $\$ 770,000$ & $\$ 1,738,128$ & $\$ 48,386,840$ & $\$ 3,370,000$ & $\$ 19,801,579$ \\
2007 & $\$ 7,172,185$ & $\$ 1,180,000$ & $\$ 922,272$ & $\$ 48,386,840$ & $\$ 3,940,000$ & $\$ 18,053,141$ \\
2008 & $\$ 6,694,039$ & $\$ 830,000$ & $\$ 673,968$ & $\$ 50,178,945$ & $\$ 3,490,000$ & $\$ 16,705,901$
\end{tabular}

